\title{
KAJIAN TEKNIS BERDASARKAN KONDISI EKSISTING BENTUK KAPAL HANDLINES DI NELAYAN LOKAL KENDARI
}

\author{
Technical Assessment Based on Existing Conditions Form of Hand Lines Ship in Kendari \\ Local Fisherman
}

Oleh :

\author{
Agus Wahyu Santosoํ, Budhi H. Iskandar2, Yopi Novita² dan Mulyono S. Baskoro ${ }^{2}$
}

1 Kementerian Kelautan dan Perikanan, Indoenesia

2 Departemen Pemanfaatan Sumberdaya Perikanan, FPIK Institut Pertanian Bogor, Indonesia

*Korespondensi:agusws@yahoo.com

\begin{abstract}
Kendari is a city in Southeast Sulawesi that has the potential for a high abundance of fish resources. That's why a lot of ship assistance will be allocated to the area. The purpose of this research is to explain the condition of the vessels in Southeast Sulawesi and to make a technical study of the handlines, namely the level of stability, resistance, and shaking period in Southeast Sulawesi. Marine ship with stability, resistance to motion, and rolling period. In the Kendari ship design group, there are three large, medium, and small groups. Of the three groups, all designs form the bow height, namely the raked bow ramps which indicates that the ship there is uniform from the shape of the bow height. The design has a different longitudinal cross-sectional shape, which is double-pointed for groups with small group sizes and transoms for large and mediumsized vessels. Estimates of stability, rolling period, and ship resistance in Southeast Sulawesi, namely from the three criteria have values that meet the criteria. Ships with medium group sizes have a good stability value between both large and small groups. Based on the ability of motion resistance, vessels with medium group size have the greatest value of resistance because ships with handline fishing gear do not require speed because of passive fishing gear. Based on the value of the rolling period of ships with medium, large, and small group sizes, they have a value according to the requirements. The results showed that handlines were the choice of fishermen to be selected as aid vessels.
\end{abstract}

Keywords: fishing vessel, handline, ship design, technical studies

\begin{abstract}
ABSTRAK
Kendari adalah kota di Sulawesi Tenggara yang mempunyai potensi kelimpahan sumberdaya ikan yang tinggi. Makanya banyak sekali bantuan kapal yang akan dialokasikan ke wilayah tersebut. Tujuan penelitian ini adalah menjelaskan kondisi armada kapal di Sulawesi Tenggara dan membuat kajian teknis kapal handlines yaitu tingkat stabilitas, tahanan dan periode oleng kapal yang ada di Sulawesi Tenggara. Kelaiklautan kapal dengan stabilitas, tahanan gerak dan rolling period. Pada kelompok desain kapal Kendari terdapat tiga kelompok besar, sedang dan kecil. Dari ketiga kelompok semua desain bentuk linggi haluan yaitu raked bow landai yang menandakan bahwa kapal disana adalah seragam dari bentuk linggi haluan. Desain tersebut memiliki bentuk penampang membujur yang berbeda, yaitu double pointed untuk kelompok dengan ukuran kelompok kecil dan transom untuk kapal dengan ukuran besar dan sedang. Estimasi dari stabilitas, rolling period dan tahanan kapal yang ada di Sulawesi Tenggara yaitu dari ketiga kriteria memiliki nilai yang memenuhi kriteria. Kapal dengan ukuran kelompok sedang, memiliki nilai stabilitas yang baik diantara kedua kelompok besar dan kecil. Berdasarkan kemampuan tahanan gerak, kapal dengan ukuran kelompok sedang, memiliki nilai tahanan yang paling besar karena untuk kapal dengan alat tangkap handline tidak memerlukan kecepatan
\end{abstract}


karena alat tangkap pasif. Berdasarkan nilai rolling period kapal dengan ukuran kelompok sedang, besar dan kecil memiliki nilai sesuai persyaratan. Hasil penelitian menunjukan bahwa kapal handlines menjadi pilihan nelayan untuk dipilih sebagai kapal bantuan.

Kata kunci: desain kapal, kajian teknis, kapal perikanan, pancing

\section{PENDAHULUAN}

Pemerintah dalam hal ini Kementerian Kelautan dan Perikanan (KKP) sedang menggalakkan program pengadaan kapal perikanan bantuan untuk nelayan. Salah satu tujuannya adalah untuk mensejahterakan nelayan dengan program bantuan dimaksud, apalagi dengan tidak diperbolehkannya kapal ikan asing beroperasi di wilayah perairan Republik Indonesia. Permasalahan yang muncul dari program ini adalah adanya beberapa kasus penolakan nelayan terhadap kapal bantuan. Dampak penolakan tersebut akan mengakibatkan kapal bantuan terbengkalai dan akan berdampak kepada kerugian Negara. Salah satu faktor penolakan nelayan adalah desain kapal perikanan yang tidak sesuai dengan kearifan nelayan lokal. Kondisi ini didukung dari beberapa kajian yang dilakukan oleh Tandipuang et al. (2015) menunjukkan bahwa terdapat adanya keraguan nelayan pada kapal bantuan terletak pada kemampuan operasional kapal ikan bantuan sampai batas maksimum beroperasi di ZEEI Indonesia. Pengadaan kapal tersebut menuai berbagai sejumlah masalah seperti salah peruntukan, spesifikasi kapal tidak memadai dan kesulitan beroperasi.

Dengan adanya penelitian ini diharapkan program bantuan kapal perikanan tersebut benarbenar dapat mencapai tujuan yang diharapkan sehingga kedepannya program pemberian kapal tersebut menjadi lebih baik dalam implementasinya dan terus berkelanjutan guna mensejahterakan nelayan kecil di wilayah Indonesia.

Tujuan dilakukannya penelitian ini adalah mendeskripsikan kondisi eksisting armada kapal handlines di Sulawesi Tenggara, serta mengestimasi kajian teknis kapal berupa tingkat stabilitas, tahanan dan periode oleng kapal di Sulawesi Tenggara. Penelitian ini diharapkan mampu memberikan sumbangan kajian tentang pemberdayaan masyarakat melalui pemberian kapal penangkapan ikan dari Kementerian Kelautan dan Perikanan (KKP) bagi nelayan.

\section{METODE}

Penelitian dilakukan di Pelabuhan Perikanan Samudera Kendari dan Pelabuhan Pendaratan Ikan Kendari di Sulawesi Tenggara. Kementerian Kelautan dan Perikanan (KKP) serta wilayah Kendari dan sekitarnya. Pengamatan dan pengambilan data di lapang dilakukan pada bulan Juli 2017 - November 2018. Pengambilan data dilakukan dalam beberapa tahapan hingga didapatkan data yang lengkap. Lokasi penelitian disajikan pada Gambar 1.

Data yang digunakan dalam penelitian ini terdiri dari data primer yaitu pengambilan sampel kapal penangkap ikan di lokasi survey seperti ukuran utama kapal, kemiringan linggi haluan, dan bentuk kasko kapal dan data sekunder seperti data sebaran dan jumlah kapal penangkap ikan di Provinsi Sulawesi Tenggara berupa laporan data statistik perikanan tangkap Provinsi Sulawesi Tenggara. Mengacu hasil lapangan diperoleh data sebanyak 32 unit kapal penangkap ikan yang beroperasi menggunakan alat tangkap handline. Selanjutnya data dimensi kapal diolah untuk mendapatkan rasio dimensi utama yang terdiri dari L/B, L/D dan B/D. Kemudian dilakukan beberapa langkah sebagai berikut:

1. Dibuat Selang Kelas dimana (Lmax - Lmin : 3).

2. Mengamati kesamaan antar lines plan ditiap kelas dan lihat kesamaan antar lines plan dibeda kelas.

3. Perumusan desain kapal tersebut akan dikelompokkan berdasarkan :

4. Stabilitas kapal.

5. Rolling motion.

6. Tahanan Kapal.

7. Hasil Pengelompokan : Dari ketiga model lines plan diatas setelah dianalisa untuk bentuk kasko kapal dibawah garis air memiliki bentuk yang mirip. Perbedaan hanya pada bentuk 
bangunan atas baik itu posisi bangunan kapal untuk kemudi kapal maupun bentuk palkah yang ada digeladak kapal.

8. Kesamaan desain kapal perikanan di wilayah perairan Kendari setelah dilakukan pengamatan dalam penelitian ini adalah beragam.

9. Hasil Forum Group Discussion (FGD): kapal 5 GT sesuai permintaan nelayan.

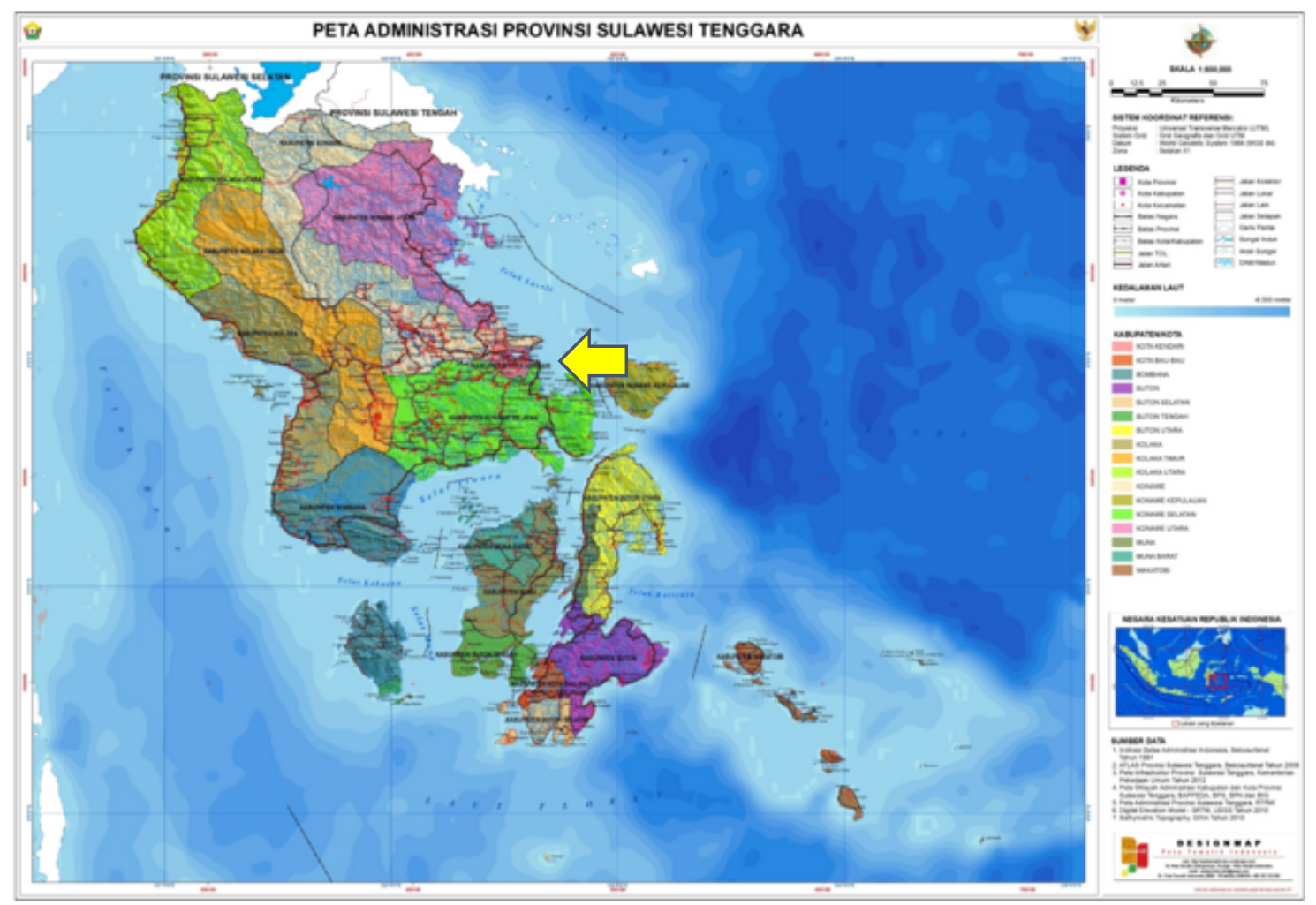

Gambar 1 Peta lokasi penelitian

Pengolahan data pada kajian ini dilakukan secara bertahap sesuai dengan tujuan penelitian sehingga tahapan pengolahan data akan dideskripsikan bertahap sesuai dengan tujuan yang ingin diperoleh.

\section{Kondisi Eksisting Bentuk Kapal di Wilayah Kendari}

\section{1) Dimensi utama}

Informasi dimensi utama kapal di wilayah Kendari seperti panjang, lebar dan tinggi kapal akan diolah ke dalam bentuk tabel. Menurut Hardjono (2010) dimensi utama dari sebuah kapal dapat menunjukkan performa dari stabilitas, kecepatan, kekuatan memanjang, olah gerak dan tahanan kapal. Selain itu, besarnya perbandingan dimensi utama juga dapat mempengaruhi konstruksi dari sebuah kapal (Zain 2010). Performa tersebut didapat dengan membandingkan data dimesni utama dengan menggunakan persamaan matematika Rasio dimensi L/B, Rasio dimensi L/D dan Rasio dimensi B/D.

\section{2) Linggi haluan}

Pengukuran tinggi haluan kapal diukur dengan menghitung jarak antara linggi tertinggi hingga bagian terbawah kapal atau yang biasanya disebut lunas. Selain itu, pengukuran kemiringan haluan kapal diukur dengan menghitung jarak dari bidang tegak haluan hingga kemiringan linggi haluan kapal. Hasil pengamatan dan pengukuran linggi haluan selanjutnya diolah dalam bentuk tabel dan gambar. Sketsa pengukuran linggi haluan ditampilkan seperti Gambar 2. 


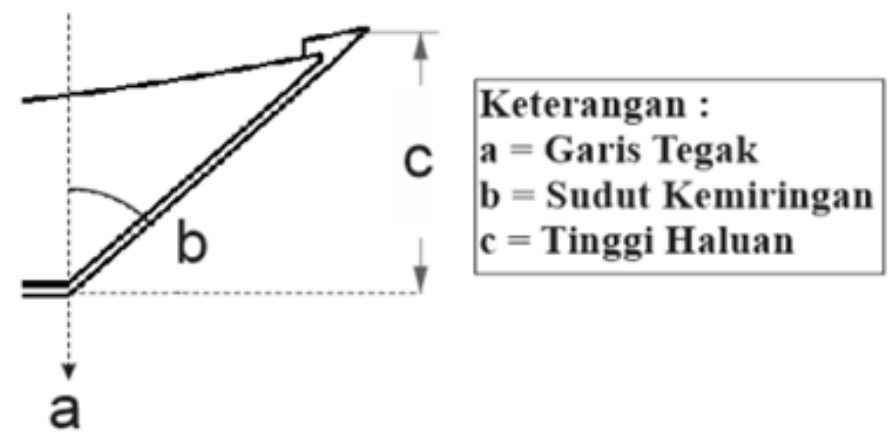

Gambar 2 Bentuk linggi haluan kapal

(Sumber : Bangun et al. 2017)

3) Bentuk badan kapal dan bangunan atas kapal

Kondisi kapal di wilayah Kendari selain dari dimensi utama dan bentuk linggi, bentuk badan kapal perlu juga diidentifikasi untuk melihat keragaman yang tercipta. Bentuk badan kapal yang akan diidentifikasi adalah bentuk secara memanjang dan juga melintang. Menurut Novita et al. (2016) bentuk kasko kapal dapat menentukan kapasitas muat, stabilitas, olah gerak dan tahanan kapal. Nilai tahanan kapal merupakan salah satu faktor yang penting untuk diperhatikan dalam mendesain bentuk kasko kapal karena dapat mempengaruhi power dan speed kapal. Bentuk badan kapal secara memanjang dapat diidentifikasi dengan melihat bentuk dari waterplan area. Selain itu, bentuk badan kapal secara melintang dapat diidentifikasi dengan melihat bentuk midship kasko kapal. hasil pengamatan dari bentuk badan kapal selanjutnya akan diolah kedalam bentuk gambar. selain itu, Bentuk bangunan atas kapal juga akan diidentifikasi untuk memperlihatkan perbedaan yang ada di daerah tersebut. bentuk bangunan kapal akan disajikan dalam bentuk gambar.

\section{Kajian Teknis Kapal Handlines di Wilayah Kendari}

1) Linesplan dan general arrangement

Kapal yang mewakili setiap kelompok disajikan gambar linesplan untuk melihat perbedaan yang ada. Eyres (2001) menjelaskan bahwa lines plan merupakan gambar yang menunjukkan rencana garis cetakan kapal yang memiliki skala yang sesuai dan terdiri dari plan (half breadth plan), body plan, profile (profile plan). Gambar lines plan didapatkan dengan meolah data seperti ukuran dimensi utama dan kelengkungan badan kapal menjadi bentuk gambar. gambar lines plan selanjutnya digunakan untuk dasar pembuatan general arrangement.

General arrangement adalah gambar yang memperlihatkan pandangan mengenai pengaturan dan posisi semua peralatan, muatan dan barang di atas dek kapal termasuk alat tangkap, alat bantu penangkapan, suprastruktur, tiang dan lainnya dari beberapa sudut pandang (Fyson 1985). Pembuatan general arrangement dilakukan dengan mengolah data letak muatan posisi muatan di atas kapal. kapal yang digunakan adalah kapal yang menjadi perwakilan dari setiap kelompok kapal.

\section{2) Parameter hidrostatik}

Parameter hidrostatis adalah nilai yang menggambarkan keragaan dari sebuah kapal secara statis di dalam air (Farhum 2006). Nilai arameter hidrostatis didapatkan dengan menggunakan persamaan naval architecture yang disajikan pada bentuk tabel seperti pada buku Gillmer dan Johnson (1982).

\section{3) Stabilitas}

Stabilitas kapal adalah kemampuan kapal untuk kembali ke posisi semula setelah mengalami gaya-gaya tarik dari luar maupun dari dalam kapal yang menyebabkan kapal itu oleng (Soegiono et al. 2006). Faktor yang dapat merubah stabilitas sebuah kapal adalah gaya berat (centre of gravity) dan gaya apung (center of bouyancy). Menurut Kok et al.(1983) titik berat adalah titik resultan gaya berat seluruh bagian kapal termasuk semua isi yang berada didalamnya yang menekan ke bawah. Selanjutnya, titik apung adalah titik berat geometris bagian kapal yang 
terbenam dalam air yang menekan ke atas dan titik metacenter adalah tinggi sudut inklinasi dari lunas kapal serta titik pusat garis yang bekerja gaya apung dan gaya berat. Bila titik gravitasi dan titik apung letaknya tidak vertikal segaris, maka hal tersebut akan muncul momen kapal yang bergerak sesuai arah momen tersebut bergerak (Pangalila 2010).

Nilai dari lengan pengembali/kopel (GZ) tersebut selanjutnya akan menjadi parameter stabilitas sebuah kapal yang akan disjaikan dalam bentuk kurva. Kurva tersebut menggambarkan hubungan antara nilai $\mathrm{GZ}$ dengan berbagai sudut kemiringan oleng kapal dalam ton displacement yang tetap (Derret dan Barras 2006). Uji kemampuan stabilitas sebuah kapal dilakukan dengan menggunakan beberapa asumsi, yaitu:

a. Kapal dalam keadaan trim even keel;

b. Kapal dalam keadaan stable equilibrium;

c. Kapal dalam keadaan kedap air.
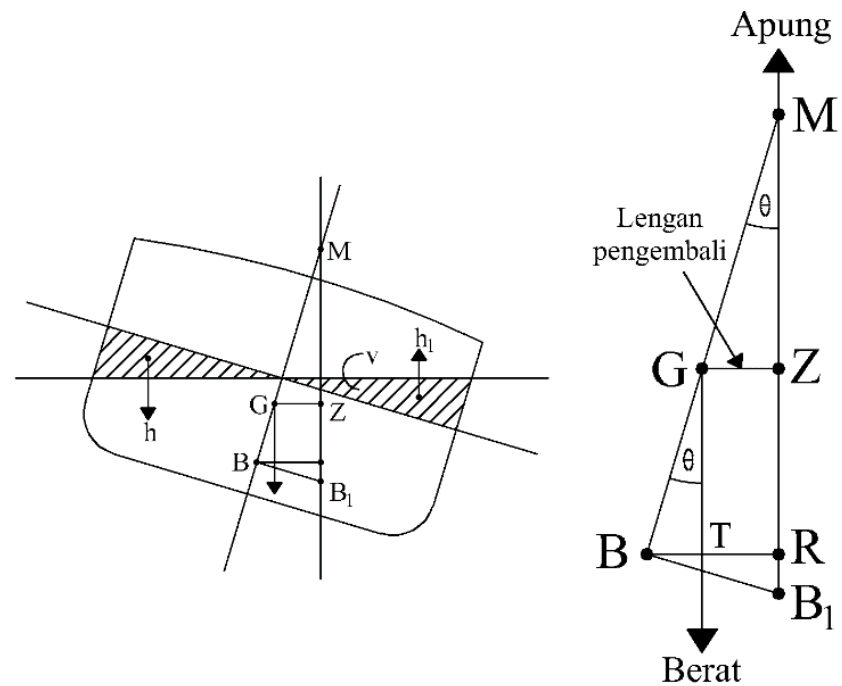

Gambar 3 Stabilitas pada sudut kemiringan kapal Sumber : Hind (1982)

4) Rolling period

Data rolling period kapal diolah dengan menggunakan metode numerik. Besar nilai periode oleng kapal didapatkan dengan menggunakan rumus TR atau rolling period dari kapal digunakan rumus pendekatan yang terdapat dalam buku Code On Intact Stability oleh International Maritime Organization (IMO).

\section{5) Tahanan kasko}

Tahanan kasko adalah tahanan total yang timbul karena adanya pengaruh dari bentuk pada bagian kasko kapal yang berada di bawah air (Manopo et al. 2012). Nilai tahanan kasko pada sebuah kapal dilakukan dengan menggunakan simulasi numerik. Data yang dibutuhkan untuk mendapatkan besar tahanan kasko kapal adalah data dimensi utama, coefficient of fiineness, dan longitudinal centre of bouyancy (LCB). Selanjutnya data tersebut diolah dengan menggunakan persamaan matematika menurut Holtrop (1984).

\section{Analisis Data}

Analisis data dilakukan untuk mencapai tujuan kajian adalah dengan menggunakan analisis komparatif numerik. Untuk menganalisis stabilitas, kurva GZ digunakan untuk membandingkan dengan nilai acuan. Kurva GZ merupakan kurva stabilitas kapal yang menunjukkan nilai GZ maksimum, nilai GZ pada setiap sudut keolengan kapal, sudut tercapainya GM (tinggi metacentre). Kurva GZ dari kapal yang dijadikan sampel akan dibandingkan dengan nilai parameter stabilitas menurut IMO code A.749(18) Ch 3. Kriteria stabilitas statis berdasarkan IMO (1995) ditunjukkan sebagai berikut: 


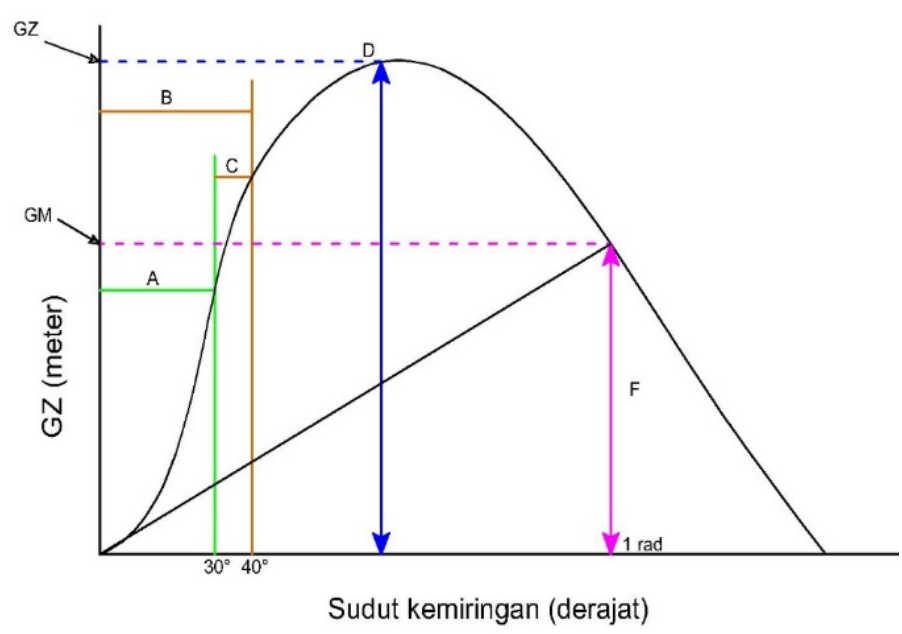

Gambar 4 Kurva stabilitas

Menurut acuan, besar nilai rolling period yang dimiliki sebuah kapal sebaiknya berada pada rentan 4,5 hingga 7 detik.

\section{HASIL DAN PEMBAHASAN}

\section{Dimensi Utama Kapal Perikanan di Kendari}

Kapal handlines di Kendari memiliki dimensi utama yang sangat beragam. Berdasarkan 32 unit kapal handlines yang telah diukur, terdapat tiga kelompok kapal yang memiliki selang kelas berbeda, yaitu kelompok kapal kecil, sedang dan besar. Hasil pengelompokan kapal handlines berdasarkan dimensi utama kapal disajikan pada Tabel 1.

Tabel 1 menunjukkan bahwa kategori kelompok kapal besar memiliki panjang (LoA) kapal sebesar 27,40 m hingga 28,41 m, dengan nilai panjang rata-rata 27,95 m. Kategori kelompok kapal besar tersebut memiliki ukuran lebar (B) kapal sebesar 3,41 m hingga $4,31 \mathrm{~m}$, dengan nilai ratarata lebar kapal sebesar $3,91 \mathrm{~m}$. Selain itu, besar ukuran tinggi kapal (D) memiliki nilai berkisar $1,22 \mathrm{~m}$ hingga $1,31 \mathrm{~m}$ dengan nilai rata-rata sebesar $1,27 \mathrm{~m}$. Nilai L/B pada kelompok kapal besar memiliki kisaran nilai sebesar 6,59 - 8,11 dengan nilai rata-rata sebesar 7,23 , nilai L/D yang berkisar 8,39-8,72 dengan nilai rata-rata sebesar 8,56 dan nilai B/D yang berkisar 1,05-1,31 dengan nilai rata-rata sebesar 1,19.

Kapal dengan kategori kelompok sedang memiliki panjang (LOA) kapal sebesar 11,20 m hingga $17,95 \mathrm{~m}$, dengan nilai panjang rata-rata sebesar 14,33 $\mathrm{m}$. Selain itu, kapal dengan kategori tersebut memiliki ukuran lebar (B) kapal sebesar 2,50 m hingga 3,50 m, dengan nilai rata-rata lebar kapal sebesar 3,01 m. Selain itu, besar ukuran tinggi kapal (D) memiliki nilai berkisar $0,95 \mathrm{~m}$ hingga $1,21 \mathrm{~m}$ dengan nilai rata-rata sebesar $1,08 \mathrm{~m}$. Selanjutnya, perbandingan nilai dimensi utama pada kelompok kapal sedang memiliki nilai kisaran L/B sebesar 4,27 - 5,19 dengan nilai rata-rata sebesar 4,72, nilai L/D yang berkisar 10,48 - 15,36 dengan nilai rata-rata sebesar 13,13 dan nilai B/D yang berkisar 2,61 - 3,09 dengan nilai rata-rata sebesar 2,77.

Kategori kelompok kapal kecil meiliki panjang (LOA) kapal sebesar 8,65 m hingga 11,12 m, dengan nilai panjang rata-rata sebesar 10,23 $\mathrm{m}$. Selain itu, kapal dengan kategori tersebut memiliki ukuran lebar (B) kapal sebesar 1,90 m hingga 3,08 m, dengan nilai rata-rata lebar kapal sebesar $2,45 \mathrm{~m}$. Selain itu, besar ukuran tinggi kapal (D) memiliki nilai berkisar 0,95 m hingga $1,30 \mathrm{~m}$ dengan nilai rata-rata sebesar $1,13 \mathrm{~m}$. Selanjutnya, perbandingan nilai dimensi utama pada kelompok kapal sedang memiliki nilai kisaran L/B sebesar 3,61 - 4,74 dengan nilai rata-rata sebesar 4,24, nilai L/D yang berkisar 8,54-10,00 dengan nilai rata-rata sebesar 9,12 dan nilai B/D yang berkisar 1,86-2,36 dengan nilai rata-rata sebesar 2,17. 
Tabel 1 Dimensi utama kapal handline di Kendari

\begin{tabular}{|c|c|c|c|c|c|c|c|c|}
\hline No & Nama Kapal & $\mathrm{L}_{\mathrm{OA}}$ & B & Depth & Item & $\mathrm{L} / \mathrm{B}$ & $\mathrm{L} / \mathrm{D}$ & $\mathrm{B} / \mathrm{D}$ \\
\hline 1 & KM. JAYA & 27.40 & 3.45 & 1.22 & \multirow{10}{*}{ Besar } & 7.94 & 22.46 & 2.83 \\
\hline 2 & KM. ANUGRAH 05 & 27.45 & 3.49 & 1.27 & & 7.87 & 21.61 & 2.75 \\
\hline 3 & KM. ANUGRAH 07 & 27.65 & 3.41 & 1.26 & & 8.11 & 21.94 & 2.71 \\
\hline 4 & KM. BERKAT & 27.76 & 3.48 & 1.31 & & 7.98 & 21.19 & 2.66 \\
\hline 5 & KM. KENDARI 01 & 27.87 & 4.05 & 1.26 & & 6.88 & 22.12 & 3.21 \\
\hline 6 & KM. UJUNG LERO & 28.05 & 4.20 & 1.27 & & 6.68 & 22.09 & 3.31 \\
\hline 7 & SINARMAS & 28.21 & 4.21 & 1.29 & & 6.70 & 21.87 & 3.26 \\
\hline 8 & KM. BERKAH SAMUDRA 07 & 28.31 & 4.23 & 1.25 & & 6.69 & 22.65 & 3.38 \\
\hline 9 & KM. FADILLAH 77 & 28.34 & 4.25 & 1.25 & & 6.67 & 22.67 & 3.40 \\
\hline \multirow[t]{2}{*}{10} & KM. EMJ LIMA & 28.41 & 4.31 & 1.28 & & 6.59 & 22.20 & 3.37 \\
\hline & $\overline{\text { RATA2 }}$ & 27.95 & 3.91 & 1.27 & RATA2 & 7.23 & 22.06 & 3.08 \\
\hline 11 & KM. SINAR SAMUDRA & 11.20 & 2.50 & 0.95 & \multirow{11}{*}{ Sedang } & 4.48 & 11.79 & 2.63 \\
\hline 12 & KM. SINAR SAMUDRA 05 & 11.25 & 2.62 & 0.95 & & 4.29 & 11.84 & 2.76 \\
\hline 13 & KM. FATMA JAYA 01 & 11.29 & 2.63 & 0.98 & & 4.29 & 11.52 & 2.68 \\
\hline 14 & KM. FATMA JAYA 02 & 11.32 & 2.65 & 1.08 & & 4.27 & 10.48 & 2.45 \\
\hline 15 & KM. FATMA JAYA 03 & 12.52 & 2.85 & 1.09 & & 4.39 & 11.49 & 2.61 \\
\hline 16 & JAYA UTAMA & 14.25 & 2.96 & 1.08 & & 4.81 & 13.19 & 2.74 \\
\hline 17 & PUTRA SINJAY & 15.12 & 3.06 & 1.08 & & 4.94 & 14.00 & 2.83 \\
\hline 18 & CARI MUATAN 09 & 16.90 & 3.40 & 1.10 & & 4.97 & 15.36 & 3.09 \\
\hline 19 & KM. SINAR JAYA 06 & 17.90 & 3.45 & 1.19 & & 5.19 & 15.04 & 2.90 \\
\hline 20 & KM. SINAR JAYA 07 & 17.91 & 3.50 & 1.20 & & 5.12 & 14.93 & 2.92 \\
\hline 21 & KM. SINAR JAYA 08 & 17.95 & 3.49 & 1.21 & & 5.14 & 14.83 & 2.88 \\
\hline \multicolumn{2}{|r|}{ RATA2 } & 14.33 & 3.01 & 1.08 & RATA2 & 4.72 & 13.13 & 2.77 \\
\hline 22 & DOA HIDAYAH & 8.65 & 1.90 & 0.95 & \multirow{11}{*}{ Kecil } & 4.55 & 9.11 & 2.00 \\
\hline 23 & NUR ALIYA SAFITRI & 8.67 & 2.10 & 0.95 & & 4.13 & 9.13 & 2.21 \\
\hline 24 & KM. RIAN UTAMA & 9.70 & 2.19 & 0.97 & & 4.43 & 10.00 & 2.26 \\
\hline 25 & KM. RITA JAYA 02 & 9.76 & 2.28 & 0.98 & & 4.28 & 9.96 & 2.33 \\
\hline 26 & DUA PUTERA & 9.87 & 2.30 & 0.99 & & 4.29 & 9.97 & 2.32 \\
\hline 27 & MANDIRI JAYA & 10.90 & 2.30 & 1.23 & & 4.74 & 8.86 & 1.87 \\
\hline 28 & KM. KENDARI MAJU & 10.92 & 2.31 & 1.24 & & 4.73 & 8.81 & 1.86 \\
\hline 29 & KM. KONAWE PUTRA & 10.95 & 2.40 & 1.24 & & 4.56 & 8.83 & 1.94 \\
\hline 30 & KM. CAKALANG & 11.00 & 3.00 & 1.28 & & 3.67 & 8.59 & 2.34 \\
\hline 31 & KOLAKA MAKMUR & 11.02 & 3.05 & 1.29 & & 3.61 & 8.54 & 2.36 \\
\hline \multirow[t]{2}{*}{32} & KM. BUTON & 11.12 & 3.08 & 1.30 & & 3.61 & 8.55 & 2.37 \\
\hline & RATA2 & 10.23 & 2.45 & 1.13 & RATA2 & 4.24 & 9.12 & 2.17 \\
\hline
\end{tabular}

Berdasarkan Tabel 1, perbandigan nilai L/B pada kategori kapal sedang dan kategori kapal kecil dibandingkan dengan kapal pada kategori kapal besar. Nilai L/B pada kelompok kapal sedang dan kecil memiliki nilai yang saling beririsan. Hal ini menunjukkan bahwa kapal pada kelompok sedang dan kecil sama-sama memiliki badan kapal yang lebih gemuk dibandingkan dengan kelompok kapal besar. Hal ini dapat dipahami mengingat kapal handline tersebut termasuk kedalam alat tangkap pasif sehingga aspek yang lebih diutamakan bukanlah kecepatan kapal melainkan kestabilan, kapasitas palka dan ruang kerja di atas kapal. Namun, berdasarkan hasil kajian Wolok et al. (2014), perbandingan L/B yang berkisar pada nilai 4,20 termasuk ke dalam golongan kapal yang ramping sehingga luas area gesekan pada lambung kapal akan bernilai kecil. Hal tersebut akan memberikan dampak positif terhadap kecepatan kapal.

\section{Linggi Haluan}

Berdasarkan pengamatan di lapangan bentuk linggi haluan yang dimiliki kapal handlines memiliki bentuk raked bow seperti yang ditunjukkan pada Gambar 5. Selain itu, besar sudut kemiringan haluan pada setiap kapal yang dijadikan sampel selanjutnya ditunjukkan pada Gambar 6.

Gambar 6 menunjukkan bahwa terdapat beragamnya kemiringan linggi haluan pada kapal handlines di wilayah Kendari. Namun, bila dikelompokkan berdasarkan kelompok ukuran kapal, kemiringan linggi haluan pada setiap kelompok kapal memiliki keseragaman. kelompok kapal besar memiliki kemiringan linggi haluan yang berkisar dari $62^{\circ}$ hingga $70^{\circ}$ sehingga rata-rata kemiringan yang dimiliki adalah sebesar $65,4^{\circ}$. Hal tersebut ditunjukkan pada KM. EMJ Lima hingga KM. Jaya. Selanjutnya, untuk kelompok kapal sedang menunjukkan kemiringan linggi 
haluan yang semakin kecil, yaitu berkisar antara $55^{\circ}$ hingga $61^{\circ}$ dengan rata-rata kemiringan linggi sebesar $57,64^{\circ}$ yang ditunjukkan pada kapal KM. Sinar Jaya 08 hingga KM. Sinar Samudera. Besar kemiringan pada kelompok kapal kecil memiliki sudut yang semakin kecil yaitu antara $45^{\circ}$ hingga $55^{\circ}$ dan rata-rata kemiringan linggi haluan sebesar $49,81^{\circ}$. Kelompok kapal kecil ditunjukkan pada KM. Buton hingga KM. Doa Hidayah. Ilutrasi kemiringan linggi haluan pada setiap kelompok kapal ditunjukkan pada Gambar 7.
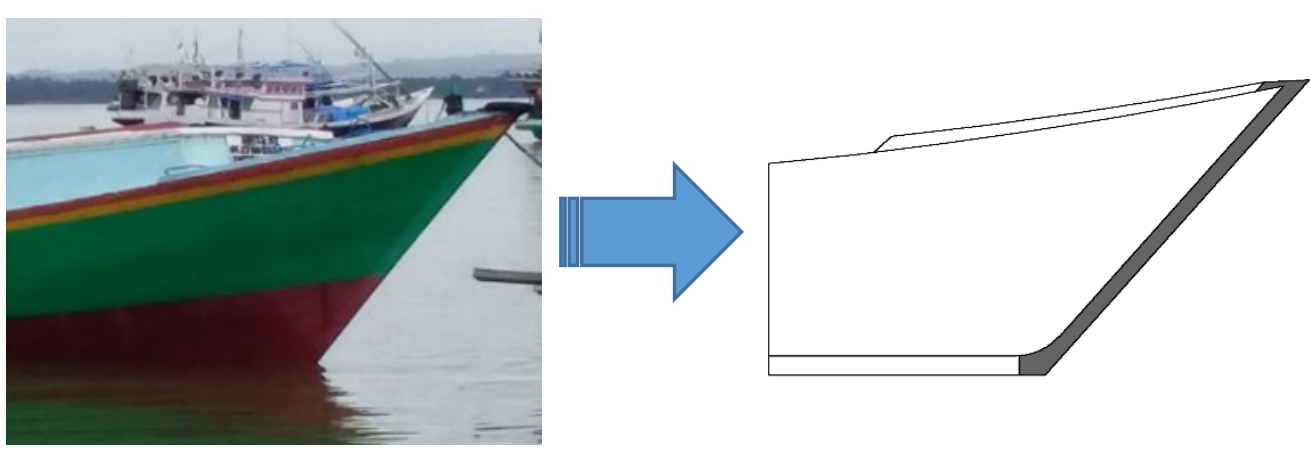

Gambar 5 Bentuk linggi haluan raked bow

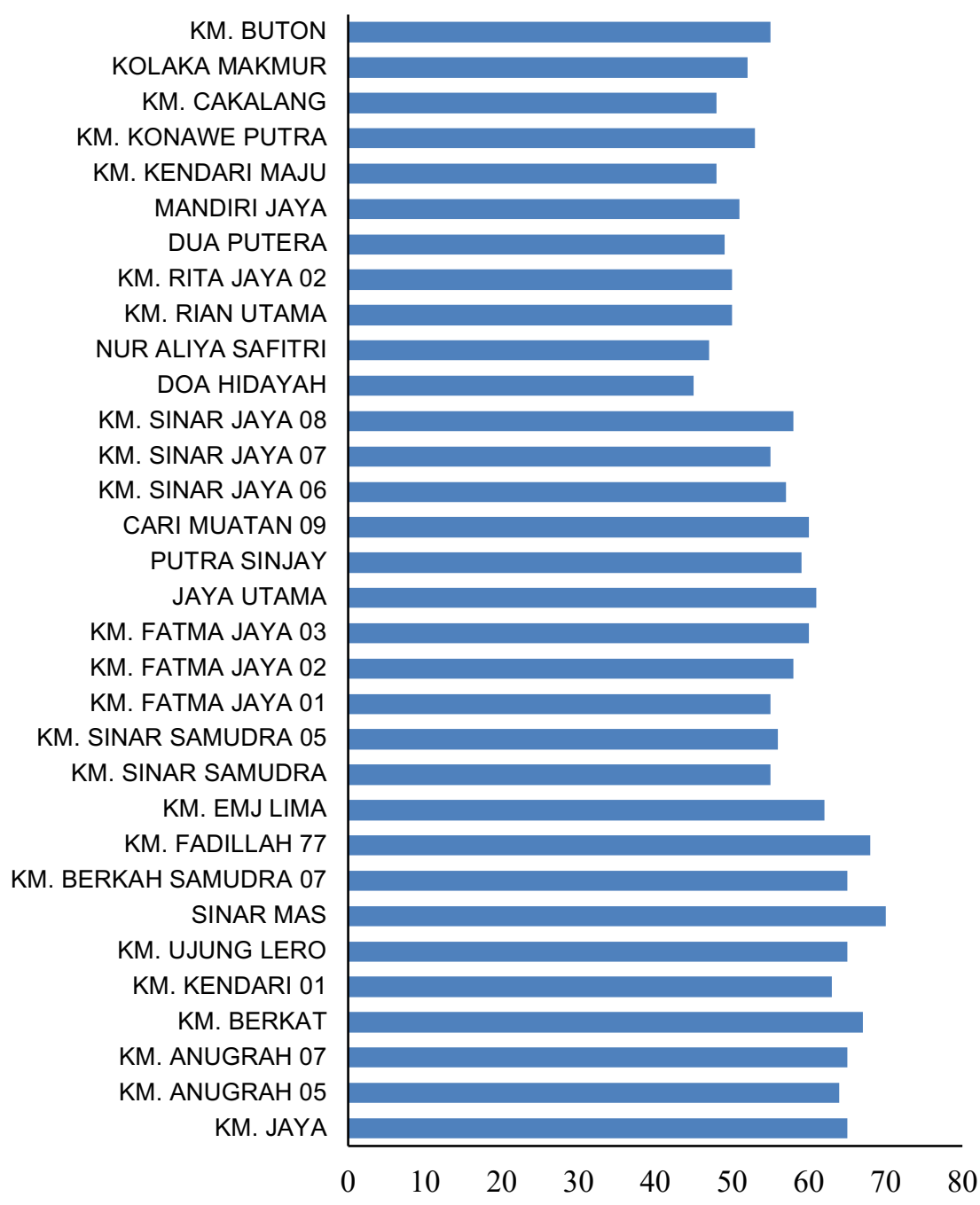

Gambar 6 Sudut kemiringan linggi haluan kapal 


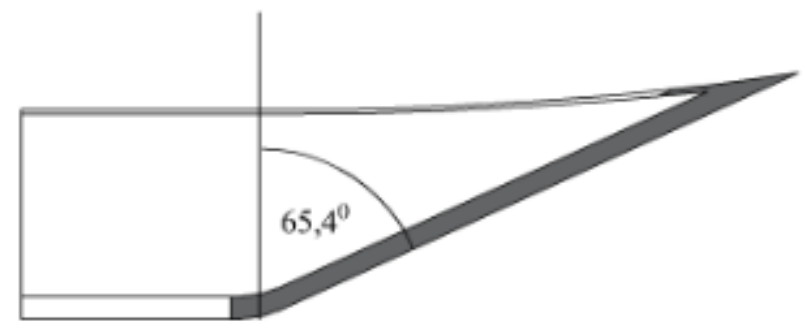

(a) Kelompok kapal besar

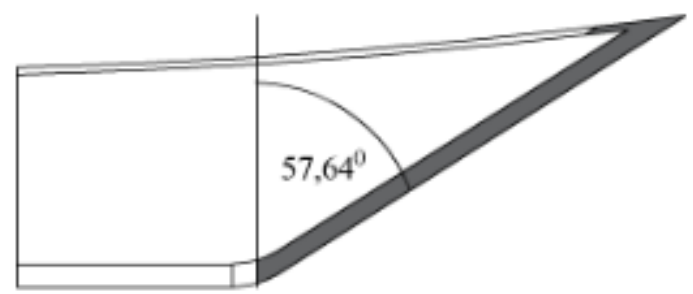

(b) Kelompok kapal sedang

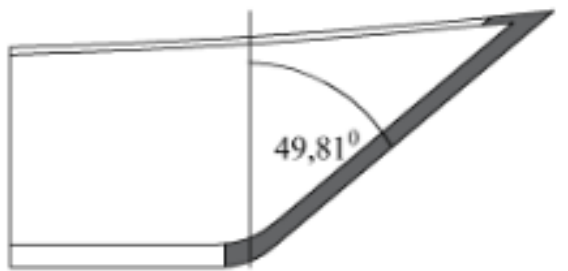

(c) Kelompok kapal kecil

Gambar 7 Rata-rata kemiringan linggi haluan

Berdasarkan Gambar 7, linggi haluan pada ketiga kelompok kapal di wilayah Kendari memiliki sudut kemiringan yang lebih dari $45^{\circ}$. Berdasarkan hasil kajian Bangun et al. (2017) terdapat dua kelompok kemiringan linggi haluan di Indonesia, yaitu kelompok di bawah dan di atas $45^{\circ}$ atau raked bow landai dan raked bow tegak. Oleh karena itu, kapal handline di wilayah Kendari termasuk ke dalam kategori raked bow landai. Selain itu jika dikaitkan dengan dimensi utama kapal, kapal di wilayah Kendari dengan linggi raked bow memiliki perbandingan L/D yang sesuai dengan kajian Bangun et al. (2017). Hal tersebut menunjukkan bahwa bentuk linggi haluan raked bow landai merupakan bentuk yang sering digunakan setelah raked bow tegak dan digunakan oleh kapal dengan dimensi panjang dan tinggi yang bervariasi. Hubungan L/D terhadap bentuk linggi haluan sendiri karena linggi haluan merupakan saah satu bagian konstruksi kapal yang menopang kekuatan memanjang kapal (Ayodhyoa 1972). Bervariasinya kemiringan linggi haluan pada kapal ini terjadi karena pembangunan kapal jenis ini dilakukan pada dua tempat yang berbeda yaitu di wilayah Kendari dan wilayah Pulau Buton.

\section{Bentuk Badan Kapal}

Bentuk badan kapal memberikan pengaruh yang luas terhadap karakter desain. Kajian Bentuk badan kapal dilakukan terhadap bentuk penampang transervsal kasko kapal. Selain itu, bentuk badan kapal juga berpengaruh terhadap tahanan gerak, unjuk kerja, kapasitas palka, ruang kerja di atas dek serta stabilitas kapal. Menurut Rouf dan Novita (2006) terdapat lima tipe bentuk kasko kapal di Indonesia, yaitu round bottom, flat bottom, u-bottom, akatsuki bottom dan hard chin bottom. berdasarkan hasil pengamatan, terdapat perbedaan bentuk penampang transversal kasko kapal pada ketiga kelompok kapal, yaitu kelompok kecil, sedang, besar. Ketiga bentuk penampang kasko tersebut disajikan pada Gambar 8. 


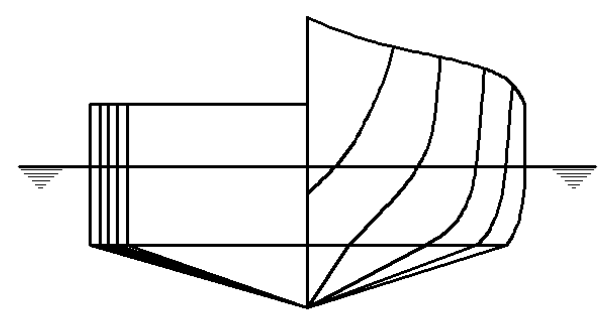

(a) kelompok kapal besar

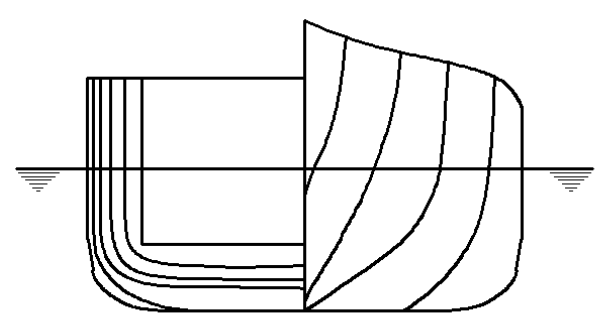

(b) kelompok kapal sedang

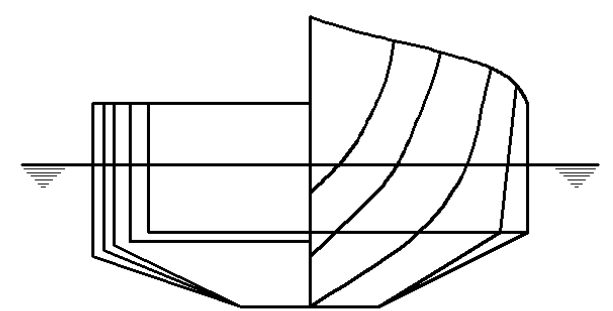

(c) kelompok kapal kecil

Gambar 8 Bentuk penampang transversal

Gambar 8 menunjukkan bentuk penampang kasko berdasarkan gambar body plan pada bagian tengah kapal. Berdasarkan Gambar 8a, bentuk penampang kasko kapal pada kelompok kapal besar termasuk ke dalam bentuk hardchin bottom. Selanjutnya, bentuk penampang kasko kapal dengan kategori ukuran sedang berdasarkan garis pada bagian tengah kapal tampak melintang, menunjukkan bentuk kasko u-bottom (Gambar 8b). Selain itu, bentuk kasko Bentuk badan kapal dengan kategori ukuran kecil berdasarkan garis pada bagian tengah kapal tampak melintang, menunjukkan bentuk kasko akatsuki (Gambar 8c).

Bentuk penampang kasko kapal yang berbeda tentu saja akan mempengaruhi performa dari pergerakan kapal itu sendiri. Menurut Rouf dan Novita (2006) kapal dengan bentuk kasko kapal seperti u-bottom dan akatsuki bottom cenderung memiliki kemampuan stabilitas yang lebih tinggi dibandingkan dengan bentuk kasko kapal lainnya. akan tetapi, jika ditinjau dari kemampuan olah geraknya, kedua bentuk kasko tersebut memiliki kemampuan yang lebih rendah dibandingkan dengan bentuk kasko lainnya. dari kedua bentuk kasko tersebut akatsuki bottom memiliki kemampuan olah gerak yang lebih baik dibandingkan dengan bentuk $u$-bottom.

Penggunaan bentuk u-bottom pada dimensi lebar dan tinggi kapal yang sama akan menghasilkan kapasitas palka yang lebih besar dibandingkan dengan bentuk kasko kapal lainnya (seperti round bottom dan round flat bottom). Bentuk kasko u-bottom, adalah bentuk yang ideal untuk kapal-kapal yang mengoperasikan alat tangkap secara statik (Fyson 1985). Hal ini dikarenakan kasko kapal berbentuk u-bottom memiliki kemampuan stabilitas yang tinggi. Hal ini juga didukung oleh hasil kajian yang dilakukan oleh Novita et al. (2008) bahwa bagi kapal yang mengoperasikan alat tangkap yang tidak memprioritaskan kecepatan dalam pengoperasiannya (handline, longline, gillnet dan trap dan sebagainya), maka bentuk u-bottom dan akatsuki sudah sesuai untuk digunakan.

Penampang kasko kapal dengan bentuk hard chin seperti yang digunakan pada kapal kelompok besar memiliki performa yang berbeda dengan kelompok kapal sedang dan kecil. Berdasarkan hasil kajian Rouf dan Novita (2006) bentuk hard chin memiliki kemampuan olah gerak yang cuku baik. akan tetapi, bentuk ini diperkirakan memiliki kemampuan laju yang lebih tinggi dibandingkan dengan bentuk kasko lainnya. hal ini diduga karena tahanan yang disebabkan oleh bentuk kasko yang demikian lebih kecil dibandingkan dengan bentuk kasko lainnya. hal ini didukung oleh kajian yang telah dilakukan Novita et al. (2008) bawasannya bentuk kasko hard chin dapat memberikan kecepatan dalam proses penangkapan, hal tersebut terjadi karena dengan bentuk kasko hard chin makan tahanan yang ditimbulkan lebih kecil dibandingka dengan bentuk $u$ bottom dan akatsuki bottom. berdasarkan hasil ketiga bentuk kasko tersebut menunjukkan bahwa penggunaan alat tangkap handlines lebih cocok digunakan oleh bentuk u-bottom, karena memiliki kemampuan stabilitas yang lebih diperlukan pada kapal yang termasuk kategori static gear. 


\section{Bentuk Water Plan Area}

Bentuk water plan area direpresentasikan dalam wujud bentuk dek kapal secara keseluruhan. Bentuk dek ini memberikan gambaran apakah bentuk kapal di wilayah Kendari memiliki bentuk yang seragam atau beragam. Berdasarkan hasil pengamatan di lapangan terdapat perbedaan bentuk kapal yang ada di wilayah Kendari, yaitu bentuk transom dan double pointed. Bentuk transom adalah bentuk memanjang kapal dengan bentuk bagian haluannya yang meruncing dan pada bagian buritan berbentuk balok membujur. Berbeda dengan bentuk double pointed, menurut Santara et al. (2014) panampang kapal dengan bentuk double pointed adalah bentuk kapal dengan lambung kiri dan lambung kanan kapal yang saling bertemu pada satu titik di ujung bagian haluan dan bagian buritan.

Penggunaan kedua bentuk penampang tersebut pun tidak berimbang terhadap bentuk kelompok berdasarkan dimensi utama. Bentuk penampang transom digunakan pada kapal yang termasuk ke dalam kelompok besar dan sedang. Sedangkan, bentuk double pointed digunakan pada kapal yang masuk ke dalam kelompok kecil. Gambar bentuk water plan area kapal disajikan pada Gambar 9.

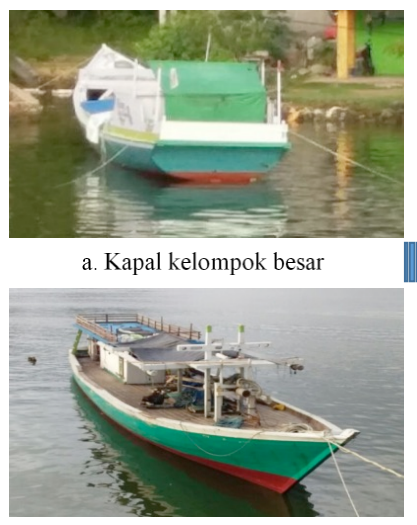

b. Kapal kelompok sedang

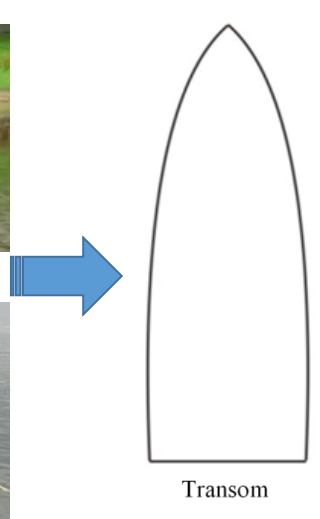

Gambar 9 Bentuk penampang kapal
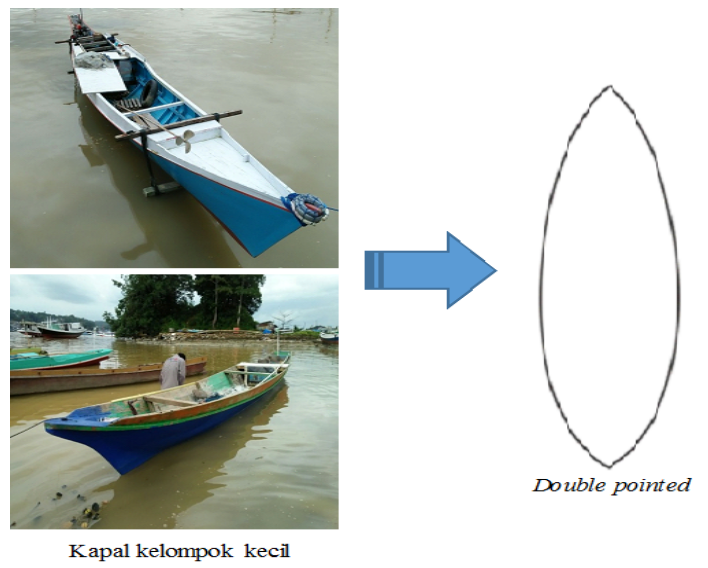

Double pointed

Berdasarkan Gambar 9 dan 10, perbedaan kedua bentuk penampang tersebut terlihat dari bentuk buritannya. Meskipun bentuk buritan kapal tidak memberikan pengaruh signifikan terhadap unjuk kerja dan stabilitas kapal, namun bentuk buritan berhubungan erat dengan efektivitas daun kemudi dalam mengendalikan arah kapal. Perbedaan tersebut terjadi pada saat pembangunan kapal dilakukan seperti pada bentuk double pointed. Kapal dengan bentuk double pointed dibangun oleh galangan tradisional di sekitar Kendari dan Pulau Buton, yang umumnya didominasi oleh pembuat kapal asal Bugis. Untuk kapal dengan kategori ukuran besar dan sedang seluruhnya memiliki bentuk transom. Sedangkan bentuk double pointed hanya ditemukan pada kapal dengan kategori ukuran kecil.

Bentuk double pointed hanya ditemukan pada kapal dengan kategori ukuran kecil. Kapal dengan bentuk dek double pointed dibangun oleh galangan tradisional di sekitar Kendari dan Pulau Buton, yang umumnya didominasi oleh pembuat kapal asal Bugis. Selain itu setiap galangan belum menetapkan kisaran kemiringan linggi haluan sehingga meskipun dibangun di galangan yang sama, variasi kemiringan linggi haluannya cukup tinggi.

Meskipun bentuk buritan kapal tidak memberikan pengaruh signifikan terhadap unjuk kerja dan stabilitas kapal, namun bentuk buritan berhubungan erat dengan efektivitas daun kemudi dalam mengendalikan arah kapal. Bentuk buritan kapal pada ketiga selang kelas dapat dikelompokkan menjadi dua jenis. Kelompok pertama adalah kapal dengan bentuk buritan yang serupa dengan bentuk haluan kapal miring/runcing. Kelompok kedua adalah kapal dengan bentuk buritan yang berbeda dengan bentuk haluan kapal datar (Bangun et al. 2017). Perbedaan bentuk buritan tersebut umumnya berkaitan dengan penggunaan jenis mesin (mesin luar atau mesin dalam), kebutuhan ruang kerja dan kebiasaan galangan dalam pembuatan kapal perikanan. 


\section{Bangunan Atas Kapal}

Kapal berukuran kecil atau pada selang kelas 3 umumnya tidak memiliki bangunan permanen di atas dek. Durasi trip penangkapan yang hanya satu hari dengan lama waktu di laut yang singkat menyebabkan nelayan membangun bangunan semi permanen dari bambu dan terpal sebagai pelindung area kerja. Sementara itu, kapal berukuran sedang pada selang kelas 2 atau kapal berukuran besar pada selang kelas 1 memiliki bangunan di atas dek karena lama trip yang lebih lama. Untuk pengoperasian kapal berukuran sedang pada selang kelas 2 membutuhkan waktu operasi antara $2-3$ hari per trip. Adapun untuk pengoperasian kapal berukuran besar pada selang kelas 1 membutuhkan waktu sekitar $5-7$ hari per trip. Selain digunakan sebagai ruang akomodasi nelayan dan perbekalan, bangunan di atas dek juga berfungsi melindungi mesin kapal dari hujan dan panas matahari. Pada umumnya, tipe bangunan di atas dek dapat dibedakan menjadi dua kelompok berdasarkan posisinya terhadap midship. Tipe pertama adalah bangunan yang berada di belakang midship kapal dan tipe yang kedua berada di tengah midship kapal.

Posisi bangunan di atas dek umumnya dibuat menyesuaikan dengan kebutuhan ruang dan permintaan pemilik kapal. Belum ada kriteria khusus yang digunakan oleh pengrajin kapal di galangan tradisional untuk menentukan bentuk, ukuran dan posisi bangunan yang di buat. Faktor kebiasaan dan pengetahuan turun temurun atau biasa disebut dengan kearifan lokal yang menjadi dasar menentukan dimensi dan spesifikasi, seperti yang ditunjukkan pada Gambar 10.
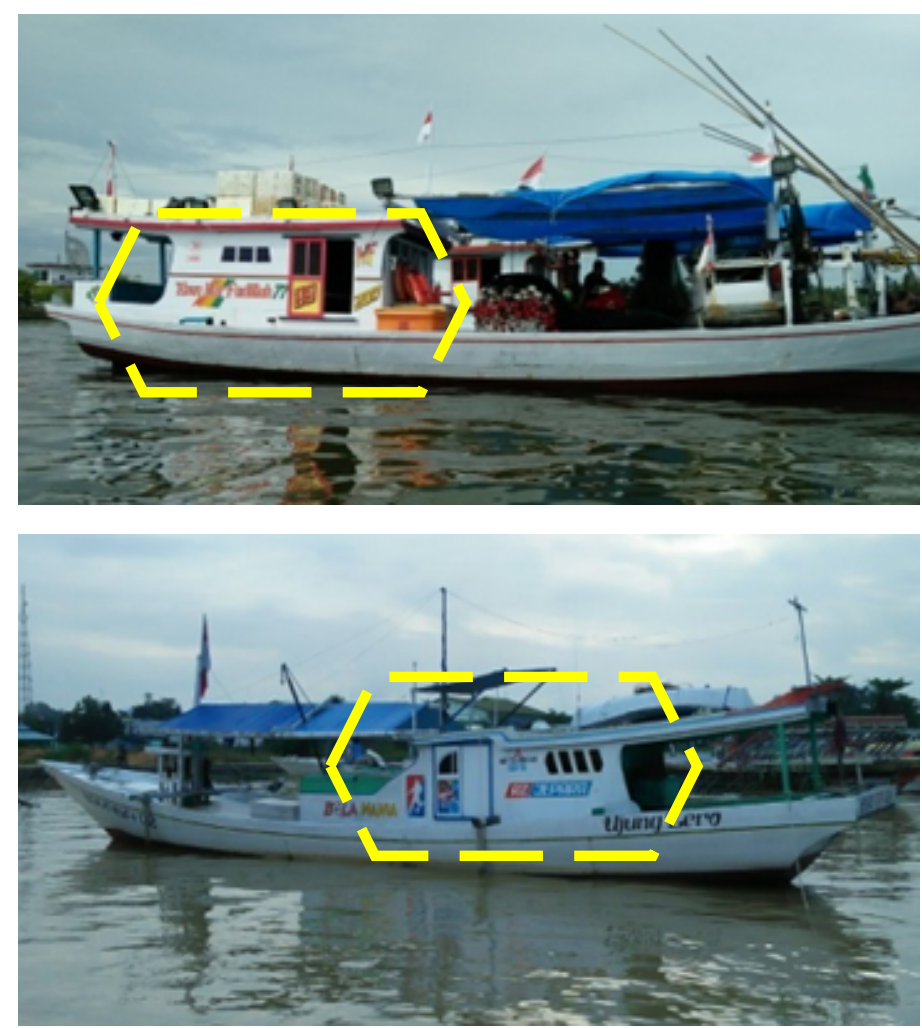

Gambar 10 Bentuk bangunan atas kapal di Kendari

\section{Stabilitas}

Kurva stabilitas ketiga kelompok kapal di daerah Kendari pada kondisi kapal kosong dan kondisi muatan penuh ditunjukkan pada Gambar 11 dan 12. 


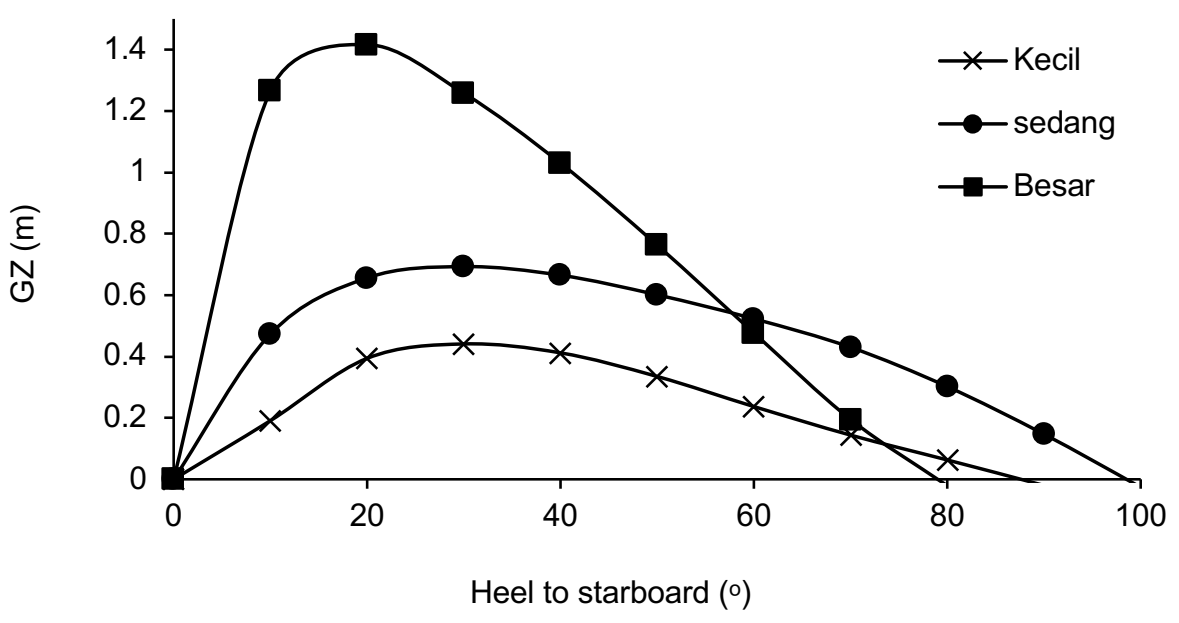

Gambar 11 Kurva stabilitas kapal handline pada kondisi kosong

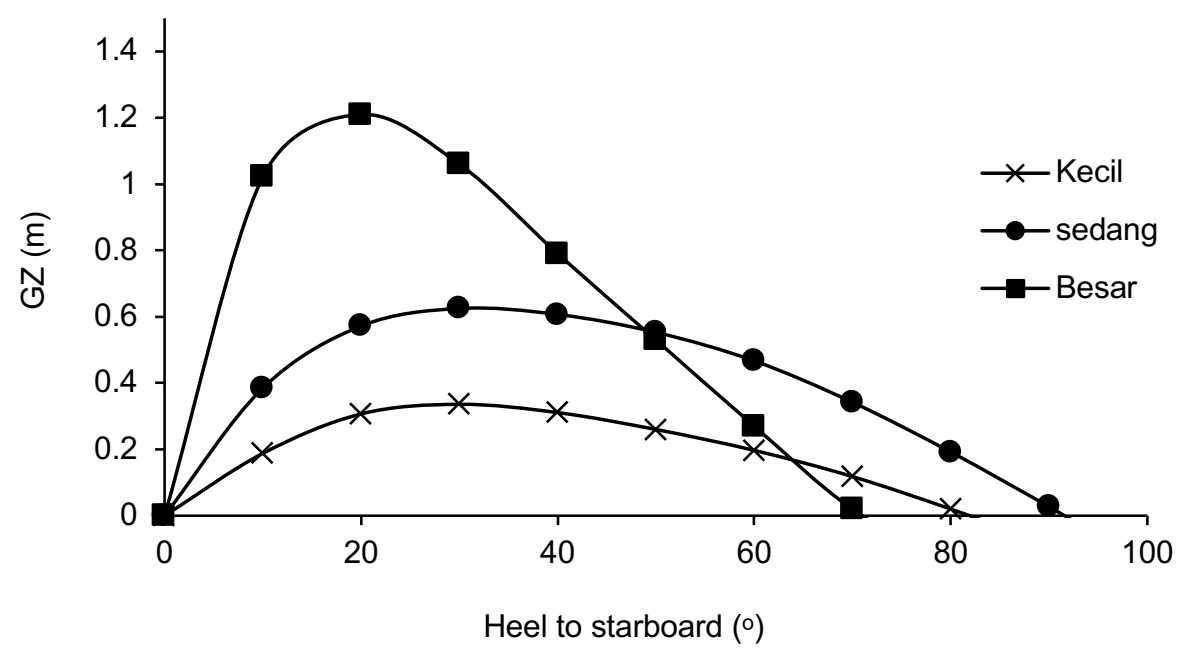

Gambar 12 Kurva stabilitas kapal handline pada kondisi muatan penuh

Nilai stabilitas yang dihasilkan pada ketiga jenis kapal tersebut memperlihatkan nilai yang sesuai dengan kriteria IMO, dimana kondisi stabilitas yang ditunjukkan pada kapal kelompok sedang dan kecil memiliki nilai stabilitas yang positif pada setiap kondisi kapal muatan penuh. Nilai GZ yang positif menunjukkan bahwa kapal dapat kembali ke posisi semula setelah terjadinya oleng, sedangkan nilai GZ yang negatif menunjukkan bahwa kapal tidak memiliki momen pengembali pada saat kapal oleng (Novita et al. 2014).

Besar nilai GM yang dihasilkan setiap jenis kapal pada semua kondisi muatan menunjukkan nilai yang positif. Perubahan muatan yang disimulasikan pada setiap jenis kapal menunjukkan adanya perbedaan pada besar nilai GM yang dihasilkan. Menurut Daud et al. (2013), Nilai GM yang positif menunjukkan titik metacentre (M) berada di atas titik gravitasi $(G)$ sehingga hal ini menghasilkan kondisi stabilitas yang baik.

\section{Tahanan Gerak}

Tahanan gerak merupakan salah satu parameter penting yang diperlukan untuk melihat kualitas kelayakan dari sebuah kapal. Beragamnya ciri khas dan bentuk badan dari sebuah kapal merupakan salah satu faktor yang dapat mempengaruhi tahanan gerak kapal itu sendiri. Besar tahanan dari sebuah kapal dapat diperlihatkan dengan membuat kurva yang menghubungkan antara tahanan gerak dan kecepatan. Kurva tahanan pada setiap kapal disajikan pada Gambar 13. 


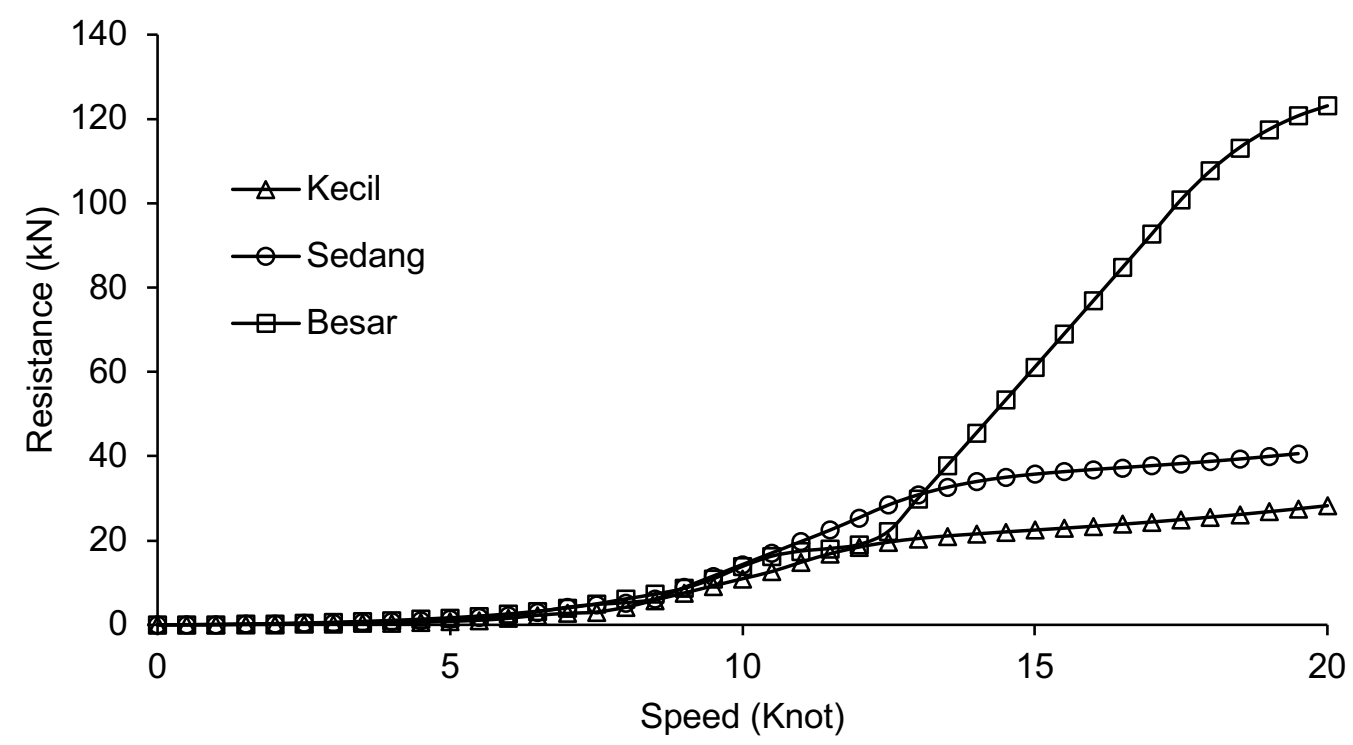

Gambar 13 Kurva tahanan kapal pada setiap jenis kapal

Berdasarkan Gambar 14 didapatkan hasil bahwa kelompok kapal besar, sedang dan kecil memiliki nilai tahanan gerak kapal yang lebih tinggi dibandingkan dengan kelompok kapal kecil. Kelompok kapal kecil menghasilkan tahanan yang lebih kecil dimulai dari saat kapal bergerak dengan kecepatan 1 knot, namun nilai tahanan yang dihasilkan tidak terlalu berbeda dengan kelompok kapal sedang dan besar. Hal tersebut menjadikan besar nilai tahanan gerak pada saat kelompok kapal kecil mencapai kecepatan dinas lebih kecil dibandingkan dengan jenis lainnya. Besar kecepatan dinas pada kapal penangkap ikan di daerah Kendari adalah 7 knot. Nilai tahanan gerak kelompok kapal kecil pada saat mencapai kecepatan dinas adalah sebesar 5,65 kN.

\section{Analisa Rolling Motion dengan Rolling Period}

Untuk menentukan atau menganalisa rolling motion maka pada pembahasan ini dilakukan perhitungan menggunakan metode periode oleng (TR) atau rolling period dari kapal digunakan rumus pendekatan yang terdapat dalam buku Code On Intact Stability oleh International Maritime Organization (IMO) 3.2.2.3, yaitu untuk kelompok kapal besar, sedang dan kecil seperti pada Tabel 2.

Tabel 2 Nilai rolling period kapal kelompok besar, sedang dan kecil

\begin{tabular}{cccc}
\hline \multirow{2}{*}{ Kelompok } & \multirow{2}{*}{ IMO } & \multicolumn{2}{c}{ Rolling period } \\
\cline { 3 - 4 } & & Nilai & Hasil \\
\hline Besar & $4,5-7,0$ detik & 6,39 detik & Memenuhi \\
Sedang & $4,5-7,0$ detik & 5,23 detik & Memenuhi \\
Kecil & $4,5-7,0$ detik & 4,68 detik & Memenuhi \\
\hline
\end{tabular}

\section{SIMPULAN}

Berdasarkan hasil analisis, dapat diambil kesimpulan sebagai berikut:

1. Deskripsi dari kondisi eksisting armada kapal light fishing di Sulawesi Tenggara, adalah sebagai berikut :

a. Pada kelompok desain kapal handline dengan light fishing terdapat 3 bagian yaitu kapal dengan ukuran kelompok besar, sedang dan kecil.

b. Dari ketiga kelompok desain bentuk linggi haluan yaitu raked bow landai yang menandakan bahwa bentuk kapal disana adalah seragam. 
c. Desain tersebut juga memiliki bentuk penampang membujur kasko yang berbeda, yaitu double pointed untuk kelompok kapal dengan ukuran kelompok kecil dan transom untuk kelompok besar dan sedang.

2. Berdasarkan nilai parameter, kapal dengan ukuran kelompok sedang, memiliki nilai stabilitas yang paling baik, dan juga memiliki nilai tahanan yang paling besar. Berdasarkan nilai rolling period kapal dengan ukuran kelompok sedang, besar dan kecil memiliki nilai sesuai persyaratan yaitu TR $=4.5-7.0$ detik.

\section{DAFTAR PUSTAKA}

Ayodhyoa AU. (1972). Fishing Boat Correpondence Center. Bogor (ID): Institut Pertanian Bogor.

Bangun TNC, Novita Y, Iskandar BH. (2017). Bentuk Linggi Haluan Kapal Penangkap Ikan (Kurang dari $30 \mathrm{GT}$ ). Albacore, 1(2): 127-137.

Sianturi DSA, Permana SM. (2013). Analisis Stabilitas terhadap Operasional Desain Kapal Ikan 20 GT di Palabuhanratu. Jurnal Kelautan Nasional, 8(3): 120-126.

Derret DR, Barras B. (2006). Ship Stability for Master and Mates. 6th Edition. London (UK): Elsevier Ltd.

Eyres DJ. (2001). Ship Contruction : fifth edition. Oxford (UK): Butterworth-Heinemann.

Farhum SA. (2006). Kajian stabilitas dan keselamatan operasional kapal pole and line Sulawesi Selatan, pada gelombang beam seas. Disertasi. Bogor (ID): Institut Pertanian Bogor.

Fyson J. (1985). Design of Small Fishing Vessels. England (UK): Fishing News Book.

Gillmer TC, B Johnson. (1982). Introduction to Naval Architecture. Maryland (US): Naval Institut Press.

Hardjono S. (2010). Identifikasi Rasio Parameter Kapal Penumpang Catamaran Berbahan FRP. Jurnal Sains dan Teknologi Indonesia, 12(3):159-165.

Hind JA. (1982). Stability and Trim of Fishing Vessels : Second edition. England (UK): Fishing News Book Ltd.

Holtrop J. (1984). A Statistical Re-Analysis of Resistance and Propulsion Data. International Shipbuilding Progress, 31(363): 272-276.

[IMO] International Martime Organization. (1995). Code on Intact Stability for All Types of Ships. London (UK): IMO.

Kok HGM, Lonkhyusen EGV, Nierich FAC. (1983). Bangunan Kapal. Zundort (NL): Martech.

Manopo AR, Masengi KWA, Pamikiran RDCh. (2012). Studi Pengaruh Bentuk Kasko pada Tahanan Kapal Pukat Cincin di Tumumpa, Bitung dan Molibagu (Provinsi Sulawesi Utara). Jurnal IImu dan Teknologi Perikanan Tangkap, 1(2):63-68.

Novita Y, Iskandar BH. (2008). Hubungan antara Bentuk Kasko Model Kapal Ikan dengan Tahanan Gerak. Buletin PSP, 17(3): 315-324.

Novita Y, Martiyani N, Ariyani RE. (2014). Kualitas Stabilitas Kapal Payang Palabuhanratu berdasarkan Distribusi Muatan. Jurnal IPTEKS PSP, 1(1): 28-39.

Novita Y, Iskandar BH, Imron M, Nurdin HS. (2016). Desain Kapal Purse Seine Modifikasi di Kabupaten Bulukumba Provinsi Sulawesi Selatan. Jurnal Perikanan dan Kelautan, 6(2): 125-136.

Pangalila FPT. (2010). Stabilitas Statis Kapal Ikan Tipe Lambut Tersanjung yang Berpangkalan di Pelabuhan Perikanan Samudera Aertembaga Kota Bitung Propinsi Sulawesi Utara. Jurnal Perikanan dan Kelautan, 6(3): 149-155.

Rouf ARA, Novita Y. (2006). Studi tentang bentuk kasko kapal ikan di beberapa daerah di Indonesia. TORANI, 16(4): 240-249. 
Santara A, Purwangka F, Iskandar BH. (2014). Peralatan Keselamatan Kerja pada Perahu Slerek di PPN Pengambengan, Kabupaten Jembrana, Bali. Jurnal IPTEKS PSP, 1(1): 53-68.

Soegiono T, Sastrodiwangso, Sasongko B, Andrianto P, Soeweify, Moernadi E, Payappo A, Wartono M, Asianto, Sukotjo, Sastrowiyono K. (2006). Kamus Teknik Perkapalan. Surabaya (ID): Airlangga University Press.

Tandipuang P. Novita Y, Iskandar BH. (2015). Kesesuaian desain operasional kapal INKAMINA 163 berbasis di PPP Sadeng Yogyakarta. Jurnal Kelautan Nasional, 10(2): 103-112.

Wolok E, Baruadi ASR, Junus S, Fachrussyah ZC. (2014). Perahu Tradisional Katinting. Gorontalo (ID): Fakultas Perikanan dan IImu Kelautan Universitas negeri Gorontalo.

Zain J. 2010. Studi Bahan dan Konstruksi Kapal Perikanan Jaring Insang di Kota Dumai, Propinsi Riau. Terubuk, 38(1): 82-94. 